\title{
WYCHOWANIE DZIEWCZĄT W NAUCZANIU JANA CHRYZOSTOMA
}

„Czym nieuprawna rola, tym zaniedbana
młodość wydająca wszędzie wiele cierni”

In Matthaeum hom. 49, 6

Jan Chryzostom, jako doświadczony duszpasterz, doskonale zdawał sobie sprawę, jak ważne jest prawidłowe wychowanie dzieci ${ }^{1}$. Jako jeden z nielicznych pisarzy wczesnochrześcijańskich zwrócił przy tym też uwagę na wychowanie dziewcząt ${ }^{2}$, kierując się wprost do ich opiekunów i wychowawców

\footnotetext{
${ }^{1}$ Pedagogiczne poglądy Jana Chryzostoma omawiają m.in.: A. Hülster, Die pädagogische Grundsätze des hl. Chrysostomus, ThG 3 (1911) 203-227; J. Seidlmayer, Die Pädagogik des Johannes Chrysostomus, Münster 1926; J. Czuj, Poglądy wychowawcze św. Jana Chryzostoma, „Przegląd Katechetyczny” 31 (1943) 7-11; J. Dumortier, L'education des enfants an IV siècle. Le témoignage de saint Jean Chrysostome, „Revue des sciences humaines” 45 (1947) 222-238; S. Abengochera, Ideas pedagógicas de S. Crisóstomo, „Helmantica” 12 (1961) 343-360; B.W. Hare, St. John Chrysostom on Education, „Prudentia” 6 (1974) 699-104; A. Cioffi, Il „De inani gloria et de educandis liberis” di Giovanni Crisostomo: famiglia e società, „Nicolas” 7 (1979) 137-144; M. Falanga, Il pensiero pedagogico di Giovanni Crisostomo, Bari 1981; W. Kania, Pierwsza rodzinna katecheza domowa w ujęciu Jana Chryzostoma, VoxP 5 (1985) z. 8-9, 215-222; H. Wójtowicz, Zadania rodziny chrześcijańskiej w nauczaniu św. Jana Chryzostoma, tamże, 201-214, spec. 203209; A. Monaci Castagno, Paideia classica ed esercizio pastorale nel IV secolo: il concetto di , synesis" nell'opera di Giovanni Crisostomo, RSLR 26 (1990) 429-459; B. Slager, Saint Basil and John Chrysostom on the Education of Christian Children, „The Greek Orthodox Theological Review” 36 (1991) 37-56; E. Stanula, Rodzina ksztattująca system wartości w ujęciu św. Jana Chryzostoma, w: Wychowanie w rodzinie od starożytności po wiek XX. Materiały z konferencji naukowej Katedry Historii Wychowania WSP w Bydgoszczy (czerwiec 1993), red. J. Jundziłł, Bydgoszcz 1994, 81-94; T. Kołosowski, Wychowanie religijno-moralne dzieci w rodzinie w świetle traktatu ,O wychowaniu dzieci” św. Jana Chryzostoma, „Seminare” 17 (2001) 405-420; P. Szczur, Problematyka społeczna w późnoantycznej Antiochii na podstawie nauczania homiletycznego Jana Chryzostoma, Lublin 2008, 327-335.

${ }^{2}$ Por. Seidlmayer, Die Pädagogik, s. 59-62; Falanga, Il pensiero pedagogico, s. 153-156; zob. też uwagi w: Szczur, Problematyka społeczna, s. 335. Drugim pisarzem chrześcijańskim, który dostrzegał potrzebę mówienia o ich edukacji, był św. Hieronim. Jego wypowiedzi miały jednak
} 
z pouczeniami, jak należy z nimi postępować, by je kształtować na dobre córki, żony i matki oraz bogobojne członkinie chrześcijańskiej wspólnoty ${ }^{3}$. Wypowiedzi te ukazują ich autora jako wnikliwego obserwatora ${ }^{4} \mathrm{i}$ bardzo dobrego znawcę charakterów niewieścich ${ }^{5}$. Złotousty nie poświęcił wprawdzie pedagogice dziewcząt osobnego pisma, a w traktacie $O$ wychowaniu dzieci ${ }^{6}$, w przeważającej części dotyczącym wychowania chłopców, jedynie zaznacza, iż to, co powiedział na ten temat, dotyczy także dziewczynek ${ }^{7}$. Uwagi o wychowaniu dziewcząt pojawiają się również w innych jego pismach, m.in. w Homiliach na I List do Tymoteusza, Homiliach na Ewangelię Mateusza, czy w Dialogu o kapłaństwie. Większość z nich jest fragmentaryczna, wręcz lapidarna, występuje w szerszym kontekście, nie związanym wprost z tematem wychowania (np. teologicznym, pastoralnym itp.). Nie można jednak oprzeć się wrażeniu, że wszystkie te wypowiedzi zebrane w całość tworzą spójny i konsekwentnie budowany program wychowawczo-edukacyjny dziewcząt ${ }^{8}$.

Jan Chryzostom ukazuje się nam tutaj jako dobry znawca historii przedmiotu, o czym świadczy podjęta w jednej z Homilii na Ewangelię Mateusza polemika z platońską koncepcją edukacji kobiet ${ }^{9}$. Przedstawiając swoje stano-

charakter prywatny i kierowane były do konkretnych osób. Znajdujemy je m.in. w listach do Lety (Epistola107, CSEL 55, 290-305) i do Gaudencjusza (Epistola 128, CSEL 56, 156-162), dwojga rodziców, których poucza, jak należy postępować z dziewczynkami przeznaczonymi do stanu dziewic. Na temat jego poglądów zob. A. Stępniewska, Wychowanie rodzinne dziewcząt w pedagogice św. Hieronima, VoxP 5 (1985) z. 8-9, 152-176.

${ }^{3}$ Zainteresowanie Chryzostoma tą kwestią spowodował być może po części fakt, iż w Kościele antiocheńskim kobiety stanowiły znaczną część wiernych, por. Szczur, Problematyka społeczna, s. 114-118; C. Militello, Donna e Chiesa: la testimonianza di Giovanni Crisostomo, Palermo 1985; R. Taft, Women at Church in Byzantium: where, when - and why?, DOP 52 (1998) 27-87.

${ }^{4}$ Według W. Cerana (Przyklady z życia wzięte w nauczaniu św. Jana Chryzostoma, w: Czasy Jana Chryzostoma i jego pasterska pedagogika, red. N. Widok, Opole 2008, 155-165), o tej cesze świadczy wiele wypowiedzi znajdujących się w homiliach, które tym samym stanowią znakomite źródło wiedzy na temat obyczajów, kultury itp. Tym cenniejsze zatem, bo poparte wnikliwą obserwacją, wydają się jego wypowiedzi dotyczące wychowania.

5 Świadectwem tego jest m.in. wypowiedź w 30. Homilii na Ewangelię Mateusza, w której Antiocheńczyk poucza męża, jak należy postępować z żoną, posiadającą złe nawyki, por. In Matthaeum hom. 30, 5, PG 57, 368, tłum. J. Krystyniacki, ŹMT 18, 361; zob. też. Szczur, Problematyka społeczna, s. 321-322.

${ }^{6}$ Por. De inani gloria et de educandis liberis (dalej: De educandis liberis), ed. A.M. Malingrey, SCh 188, Paris 1972, thum. W. Kania, PSP 13, Warszawa 1974, 157-185, przedruk: BOK 19, Kraków 2002, 73-105 (dalej cytuję według tego ostatniego wydania).

${ }^{7}$ Por. De educandis liberis 90, SCh 188, 196, BOK 19, 103: „Niech i matka w podobny sposób trudzi się w wychowaniu swej córki".

${ }^{8}$ U Jana Chryzostoma te dwa procesy w przypadku dziewcząt stanowią integralną całość, dlatego też omawiając problem wychowania terminy „wychowanie” i „edukacja” będą używane zamiennie.

${ }^{9}$ Por. In Matthaeum hom. 1, 4, PG 57, 19A, ŹMT 18, 21: „Na podstawie ich własnych dzieł [chodzi tutaj o Państwo Platona] okazało się, że myśli w nich zawarte poddał im jakiś zły duch i złośliwy szatan wojujący z naszą naturą, nieprzyjaciel zdrowego rozsądku ( $\sigma \omega \varphi \rho o \sigma v ́ v \eta)$, wróg 
wisko, Antiocheńczyk, podobnie jak Platon, odwoływał się do pojęcia ludzkiej natury $(\varphi v ́ \sigma ı)^{10}$. Jednak jego wizerunek kobiety różni się zasadniczo od platońskiego: uformowały go w znacznej mierze przekazy Pisma Świętego (m.in. o stworzeniu kobiety, o jej pierwszym nieposłuszeństwie oraz o związanym z tym jej ziemskim powołaniu, uzasadniającym pozycję i rolę społeczną). One też stanowią ,teoretyczną" bazę jego nauki dotyczącej wychowania dziewcząt, wyznaczają jej tory. Omawiając poniżej tę myśl, nie możemy zatem pominąć tak podstawowego zagadnienia, jakim są jej podstawy biblijne. Od ich przedstawienia rozpoczniemy tedy prezentację poglądów, stanowiących przedmiot niniejszego artykułu.

1. Biblijne podstawy pedagogiki Jana Chryzostoma. Podejmując kwestię biblijnych podstaw Chryzostomowj nauki o wychowaniu dziewcząt, należy zwrócić uwagę przede wszystkim na egzegezę trzech pierwszych rozdziałów Księgi Rodzaju ${ }^{11}$, którą Złotousty obszernie komentował w kazaniach i homiliach $^{12}$. Nie robił tego, co prawda, w sposób systematyczny ${ }^{13}$, jednak lektura

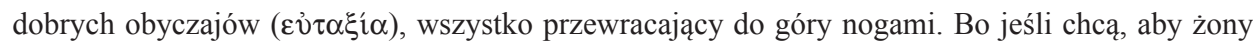
były wszystkim wspólne, nagie zaś dziewczęta prowadzą do palestry na widok publiczny, potajemnie kojarzą małżeństwa, wszystko razem mieszając i zmieniając (oraz przekraczając granice natury), to cóż innego można powiedzieć? O tym, że wszelkie tego typu nauki są wynalazkiem diabła i sprzeciwiają się naturze, może nas przekonać sama natura, dla której są one nie do zniesienia”. Źródłem przedstawionego w V księdze Państwa postulatu, by kobiety stanowiły wspólną własność (Respublica 457C-D, co później powtórzył w II wieku gnostyk Epifanes) oraz (o czym Jan Chryzostom nie wspomniał), by dziewczęta były kształcone kolektywnie, zwłaszcza w zakresie wychowania fizycznego (Respublica 457A-B), był pogląd Platona o równości natur męskiej i żeńskiej (przy jednoczesnym uznaniu słabości kobiety) oraz o takich samych obowiązkach obu płci wobec państwa (Respublica 455E; por. tamże 256A), którego prawidłowe funkcjonowanie winno być celem nadrzędnym wszystkich obywateli (zob. R.S. Frank, Education of women according to Plato, w: R.C. Lodge, Plato's theory of education, London $2000^{4}, 287-307$; L. Turos, Platon o wychowaniu, Warszawa 2001, 197-202). Pisarze chrześcijańscy w poglądach tych widzieli, tak jak Jan Chryzostom, źródło liberalizacji obyczajów (por. Respublica 457A-B) oraz zagrożenie dla rodziny - tak jak Laktancjusz (Divinae Institutiones III 21; por. M. Kosznicki, Ksztatcenie i wychowanie w literaturze zachodniego chrześcijaństwa od I do IV wieku, Gdańsk 1999, 85).

${ }^{10}$ Chodzi tutaj o istotne (gatunkowe) cechy człowieka. W takim znaczeniu termin upowszechnił się w literaturze chrześcijańskiej w IV wieku. Terminu tego w tym znaczeniu Jan Chryzostom używa m.in. w Homiliach na Księgę Rodzaju.

${ }^{11} \mathrm{O}$ wpływie, jaki miała ta księga na poglądy pisarzy antiocheńskich na temat kobiety, piszą m.in. S. Zincone, Il tema dell'uomo/donna imagine di Dio nei Commenti paolini e a Gn di area antiochene (Diodoro, Crisostomo, Theodoro, Teodoreto), ASE 2 (1985) 103-113; zob. też G.S. Gasparo, La donna nell'esegesi patristica di Gen 1-3, w: La Donna nel pensiero cristiano antico, a cura di U. Mattioli, Genova 1992, 17-51.

${ }^{12}$ Por. In Genesim sermones 1-9, SCh 433, PG 54, 581-630, thum. S. Kaczmarek: Homilie na Księge Rodzaju. Seria pierwsza Rdz 1-3, ŹMT 45, Kraków 2008; In Genesim hom. 1-67, PG 53, $21-54,580$.

${ }^{13}$ Por. S. Kaczmarek, Autor i odbiorcy homilii (wstęp), ŹMT 45, 28. 
kazań 1-9 pozwala odtworzyć logikę jego wywodów i wskazać wypowiedzi na ten temat. Punktem wyjścia jest tu wiersz Rdz 1, 26, mówiący o stworze-

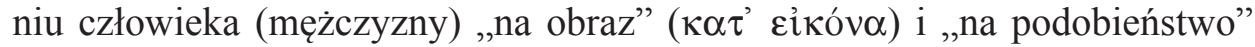

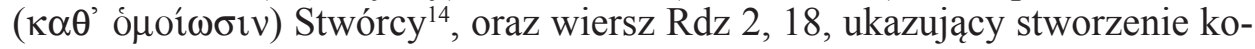
biety, powołanej do istnienia jako pomoc dla mężczyzny ${ }^{15}$. Antiocheńczyk nasz zwraca tutaj uwagę na fakt, iż kobieta podobnie jak mężczyzna, została stworzona przy pomocy tego samego słowa - „uczynić" $\left(\pi\right.$ oíعıv) ${ }^{16}$. Z czego wyciąga wniosek, iż powstała ona tak samo, jak on ,na obraz” $i$,na podobieństwo" 17 , a co za tym idzie, że będąc taka ,jak on”, była mu równa w godności

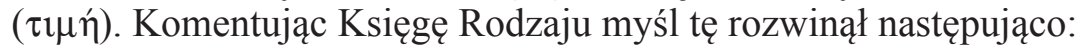

„Przed nieposłuszeństwem niewiasta była przecież równa w godności mężczyźnie, bo kiedy Bóg ją ukształtował, przy stwarzaniu niewiasty użył takich samych słów, jak przy kształtowaniu mężczyzny. Jak bowiem w odniesieniu do niego rzekł: «Uczyńmy człowieka na obraz i na podobieństwo nasze», a nie rzekł: «Niech się stanie mężczyzna», tak i w jej przypadku nie powiedział: «Niech się stanie niewiasta», lecz i tutaj: «Uczyńmy dla niego pomoc», i nie po prostu «pomoc», lecz «jak on», znowu ujawniając równą godność"18.

Kolejno wyjaśnia też znaczenie dwóch kluczowych terminów - „na obraz” i „na podobieństwo”. W dwóch kazaniach (2 i 3), odwołując się ponownie do wiersza $\mathrm{Rdz} 1,26$, analizuje treść pojęcia $\kappa \alpha \tau$ ' eikòv $\alpha$, i na bazie tego oraz na podstawie przyjętej definicji obrazu, według której stanowi on „to, co jest niezmienne z formy Boga" ${ }^{19}$ - stwierdza, iż chodzi tutaj o obraz władzy $(\dot{\alpha} \rho \chi \eta ்)^{20}$. Przejawiać się ona miała w panowaniu nad zwierzętami, a jej symbolicznym wyrazem było nadawanie im imion ${ }^{21}$. Akt ten ważny był o tyle, że ukazywał człowieka jako istotę rozumną. Chryzostom kwestii tej jednak nie rozwija, skupiając się bardziej na takich aspektach „bycia obrazem”, jak wolność oraz związana z nią godność.

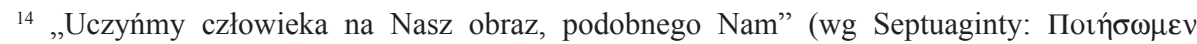

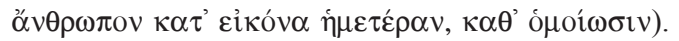

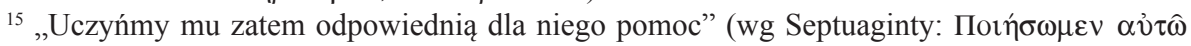




nych stworzeń, które zostały stworzone przy pomocy słów „Niech się stanie”, por. In Genesim hom. 2,1, SCh 433, 184, ŹMT 45, 63-64.

${ }^{17}$ Por. V. Harrison-Nonna, Women and the Image of God according to St. John Chrysostom, w: In Lordly Eloquence. Essays on Patristic Exegesis in honour of Robert Louis Wilken, ed. P. Blowers, Grand Rapids 2002, 259-279.

${ }^{18}$ In Genesim sermo 4,1, SCh 433, 222, ŹMT 45, 74.

${ }^{19}$ In Genesim sermo 2, 2, SCh 433, 194, ŹMT 45, 66.

${ }^{20}$ Jan Chryzostom wyróżnia jeszcze obraz istoty (ov̉oí $\alpha$ ). Twierdzi jednak, iż w Rdz 1, 26 mowa jest jedynie o obrazie władzy.

${ }^{21}$ Por. In Genesim sermo 3, 2. 
W jego 9. kazaniu pojawia się jeszcze inne znaczenie „bycia obrazem”,

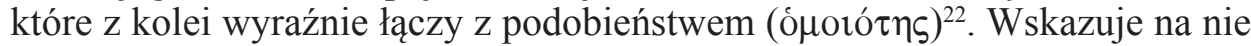
P. Szczur stwierdzając, iż Homileta rozumie przez nie „moc [podkreślenie - A.Z.] bycia podobnym”, pozwalającą na „nabywanie boskich cech”, czyli „możliwość [podkreślenie - A.Z.] stawania się łagodnym, kochającym, łaskawym, twórczym i pełnym cnót, podobnie jak Bóg"23. Jeśli zatem tak rozumiany „obraz” stanowiłby samą możliwość, to „podobieństwo” odzwierciedlałoby już konkretne cechy (treści), z racji których ono zachodzi. Takie rozumienie potwierdza sam nasz Antiocheńczyk, który wyrażeniu $\kappa \alpha \theta^{\prime}$ ó $\mu o^{\prime} \omega \sigma \imath v$ nadaje następujące znaczenie:

„«Na podobieństwo» dotyczy natomiast bycia uległym i cichym (Mt 11, 29) 24 oraz naśladowania $\mathrm{w}$ miarę możliwości Boga $\mathrm{w}$ dziedzinie cnoty, jak rzecze Chrystus: «Stawajcie się podobni do Ojca mojego w niebiosach» (Mt 5, 45)»25.

Według Jana Chryzostoma, grzech pierworodny zniszczył jednak w człowieku (proporcjonalnie do winy) to wszystko, co wynikało z jego godności ${ }^{26}$. Skoro zatem kobieta ponosi większą odpowiedzialność (gdyż jako pierwsza złamała zakaz Stwórcy i do tego samego nakłoniła męża), ponosi tedy większą karę: Złotousty twierdzi, że jest to utrata panowania i wolności. Powołując się na $\operatorname{Rdz} 3,16$, gdzie mowa jest też o powołaniu do małżeństwa i macierzyństwa $^{27}$, stwierdza, iż od tej pory niewiasta staje się poddana mężczyźnie ${ }^{28}$. Myśl tę rozwija w formie parafrazy:

„Uczyniłem cię - powiada [Antiocheńczyk odwołuje się tutaj do słów samego Boga - A. Z.] - równą w godności. Nie użyłaś w dobry sposób władzy,

${ }^{22}$ Por. In Genesim sermo 9, 3.

${ }^{23}$ Szczur, Problematyka spoleczna, s. 83.

${ }^{24}$ S. Kaczmarek sugeruje, iż określenie to jest aluzją do słów Chrystusa wypowiedzianych w Mt 11, 29: „Weźcie moje jarzmo na siebie i uczcie się ode Mnie, bo jestem cichy i pokorny sercem, a znajdziecie ukojenie dla dusz waszych", por. ŹMT 45, 69, przypis 10.

${ }^{25}$ In Genesim sermo 3, 1, SCh 433, 204, ŹMT 45,69. Podobny pogląd pojawia się u Grzegorza z Nyssy (Oratio de beatitudinibus 1 ).

${ }^{26}$ In Genesim sermo 3, 2, SCh 433, 212, ŹMT 45, 71: „Lecz skoro pojawił się grzech, zostało zniszczone także to, co wynikało z godności”.

${ }^{27}$ Por. Rdz 3, 16: „Do niewiasty powiedział: «Obarczę cię niezmiernie wielkim trudem brzemienności, w bólu będziesz rodziła dzieci, ku twemu mężowi będziesz kierować swe pragnienia, on zaś będzie panował nad tobą»".

${ }^{28}$ Idąc za myslą L.F. Pizzolato, charakteryzującego analogiczne wypowiedzi św. Ambrożego, można stwierdzić, iż pogląd Jana Chryzostoma nie ma jednak charakteru antyfeministycznego, gdyż niższość kobiety rozpatruje on w kategoriach moralnych, a nie ontycznych, por. La coppia umana in sant Ambrogio, w: Etica sessuale e matrimonio nel cristianesimo delle origini, ed. R. Cantalamessa, Milano 1976, 180-211; Kosznicki, Kształcenie i wychowanie, s. 92; por. też V. Karras, Male domination of woman in the writings of Saint John Chrysostom, „The Greek Orthodox Theological Review” 36 (1991) 131-140. Sam Antiocheńczyk podkreśla, że niewola nie wynika z natury, lecz z grzechu (In Genesim sermo 5, 1). 
przejdź w poddaństwo. Nie uniosłaś ciężaru wolności, przyjmij niewolę. Nie umiałaś panować i dałaś tego dowód w konkretnej próbie, bądź zatem wśród rządzonych i uznaj w mężczyźnie pana"29.

Charakteryzując tę nową relację, Złotousty odwołuje się do często powracających w jego wypowiedziach metafor, w których mężczyzna (mąż) przyrównywany jest do króla lub do głowy (podczas gdy kobieta do dowódcy wojsk lub do ciała) ${ }^{30}$. Powiada za św. Pawłem (1Kor 11, 7 i 10), iż tak jak mężczyzna jest chwałą Boga, tak kobieta jest chwałą męża (głowy), co w sposób symboliczny wyraża odkryta głowa u niego i zakryta u niej ${ }^{31}$. Nasz Kaznodzieja stwierdza ponadto, powołując się po raz kolejny na autorytet św. Pawła, że za tą zależnością idą: nakaz uczenia się „,w cichości” oraz zakaz nauczania publicznego, które Apostoł formułuje w I Liście do Tymoteusza (2, 11-14) ${ }^{32}$. W komentarzu do tej perykopy nasz Biskup wyjaśnia:

„«Niewiasta - rzecze [św. Paweł - A. Z.] - niech się uczy w cichości (દُv

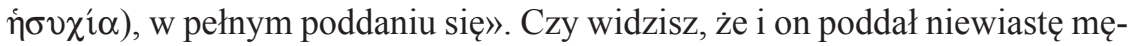
żowi? [...] «Niewieście natomiast - rzecze - nie pozwalam nauczać», bo raz


bo raz źle użyła władzy. «Lecz żeby pozostała w cichości». Podał również przyczynę. "Adam bowiem - rzecze - nie pozostał zwiedziony, niewiasta natomiast po zwiedzeniu dopuściła się przestępstwa ( $\pi \alpha \rho \alpha ́ \beta \alpha \sigma ı \varsigma) »$. Dlatego usunął ją z nauczycielskiego tronu. Ten zatem, kto nie umie pouczać, niech się uczy. Gdyby nie chciał się uczyć, lecz pragnął pouczać, i siebie samego

${ }^{29}$ In Genesim sermo 4, 1, SCh 433, 224, ŹMT 45, 74-75.

${ }^{30}$ Por. In Epistulam I ad Corinthios hom. 34, 3; In Ephesios hom. 20, 4; In Matthaeum hom. 17, 2.

${ }^{31}$ Por. In Genesim sermo 2, 2, SCh 433, 194, ŹMT 45, 66. Należy podkreślić, iż układ ten odpowiadał faktycznie istniejącemu, patriarchalnemu modelowi rodziny (zob. A. Eckmann, Starożytna rodzina grecka i rzymska, VoxP 5:1985, z. 8-9, 29-49), w której ojciec (mąż), jako pater familias mógł na mocy przysługującego mu prawa, decydować o losie: żony (manus), dzieci (patria potestas) i niewolników (dominica potestas). Najsurowszym prawem wynikającym z mocy urzędu pater familias było „prawo życia i śmierci” (ius vitae ac necis), stosowane jeszcze w okresie wczesnego cesarstwa; formalnie zniesione zostało dopiero przez Teodozjusza, a więc w czasach bliskich Janowi Chryzostomowi (na temat obowiązków i przywilejów wynikających z urzędu pater familias por. L.M. White, Paul and Pater Familias, w: Paul in the Greco-Roman World, ed. J.P. Sampley, Harrisburg 2003, 457-487).

${ }^{32}$ Por. 1Tm 2, 11-14 (wg Biblii Tysiąclecia): „Kobieta niechaj się uczy w cichości z całym poddaniem się. Nauczać zaś kobietom nie pozwalam, ani też przewodzić nad mężem, lecz [chcę, by] trwała w cichości. Albowiem Adam został pierwszy ukształtowany, potem Ewa. I nie Adam został zwiedziony, lecz zwiedziona kobieta popełniła przestępstwo”. Komentatorzy zwracają uwagę, iż zakaz ten dotyczył prawdopodobnie spotkań liturgicznych. O wpływie tej perykopy na tradycję patrystyczną pisze W. Myszor, Chrześcijanie w Cesarstwie Rzymskim II I III wieku, Katowice 2005 148-162 (Kobieta w chrześcijaństwie pierwszych wieków). 
zgubić, i w dodatku uczniów, do tego właśnie doszło wówczas w przypadku niewiasty" 33 .

Według Jana Chryzostoma, nie może tedy dziwić, że kobiety nie tylko nie powinny uczyć - to bowiem jest zadaniem mężczyzn - ale nawet nie powinny być pouczane inaczej, jak tylko za pośrednictwem swojego opiekuna: męża lub ojca. Pogląd ten ilustruje wypowiedź z 17. Homilii na Ewangelię Mateusza, w której Złotousty (odwołując się znowu do metafory męża-głowy i kobiety-ciała) thumaczy słuchaczom, dlaczego Jezus kieruje swoją naukę do mężczyzn, a nie do kobiet, mimo, iż jego nauka dotyczy również niewiast ${ }^{34}$ :

„Jednakże wszędzie daje wspólne prawa: mówiąc do głowy, daje też upomnienie dla całego ciała. Kobietę i mężczyznę uważa za to samo stworzenie i nigdzie nie rozróżnia rodzaju"35.

Jan Chryzostom, odmawiając kobiecie prawa do niezależności (wolności, panowania) oraz do nauczania nie odmawia jej jednak, jak stwierdziliśmy powyżej, prawa do uczenia się, ani tym bardziej, do rozwoju duchowego. Tłumaczy to tym, iż kobieta jako istota stworzona "na obraz i podobieństwo" Boga, posiadała taki sam umysł i taką samą dyspozycję do cnót, jak mężczyzna ${ }^{36}$. Złotousty, pogląd ten wyraża m.in. w jednej z Homilii na Ewangelię Mateusza, gdzie zwraca uwagę na to, że kobiety, tak samo jak mężczyźni, pra-

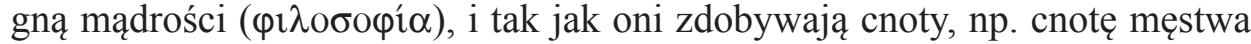
( $\alpha \nu \delta \rho \varepsilon \hat{\imath} \alpha$ ), którą w wysokim stopniu posiada wiele niewiast. $Z$ tym, że chodzi tutaj o męstwo ducha, a nie ciała, bowiem wróg, z którym one walczą ma charakter duchowy a nie fizyczny. Przy tej okazji nasz Antiocheńczyk odnosi się krytycznie do poglądów prawodawcy spartańskiego Likurga oraz Platona,

${ }^{33}$ In Genesim sermo 4, 1, SCh 433, 224, ŹMT 45, 75; por. In Ephesios hom. 9, 1.

${ }^{34}$ Sam Antiocheńczyk w swojej pracy duszpasterskiej na ogół stosował się do tych zasad. W homiliach rzadko zwracał się bezpośrednio do kobiet. Swoje słowa przeważnie kierował do mężczyzn, dodając na koniec, iż to, co powiedział, dotyczy również niewiast, por. Szczur, Problematyka społeczna, s. 115.

${ }^{35}$ In Matthaeum hom. 17, 2, PG 57, 257, ŹMT 18, 217.

${ }^{36} \mathrm{Nie}$ była to kwestia nowa. Na podobieństwo cnót, rozumianych jako pozytywna cecha moralna mężczyzn i kobiet, wskazywali już myśliciele helleńscy i hellenistyczni: Sokrates (Xenophon, Symposium 2, 9), Platon (Meno 73A-C), cynik Antystenes (Diogenes Laertius, De vita philosophorum VI 12), Arystoteles (Politica 1259B, 1260A), stoik Kleantes - autor traktatu $O$ tym, że cnota jest jedna i ta sama u mężczyzn i kobiet (Diogenes Laertius, De vita philosophorum VII 175) i Muzoniusz Rufus (Stobaius, Anthologia II 31, 123) oraz Plutarch (w Mulierum virtutes); por. E.M. Engel, Women's Role in the Home and State: Stoic Theory reconsidered, „Harvard Studies in Classical Philology” 101 (2003) 267-288; J. Szymańska, Traktat Plutarcha z Cheronei „O cnotach kobiet”: wprowadzenie, „Studia Antyczne i Mediewistyczne” 2007, nr 5(40), 25-34. Stoik Muzoniusz Rufus nauczał też, że kobieta posiada taki sam umysł ( $\lambda$ ó Anthologia II 31, 126). 
którzy oczekiwali, by kobiety wzorem mężczyzn rozwijały przede wszystkim siłę i sprawności fizyczne ${ }^{37}$ :

„Nie mniej od mężczyzn poszukują one mądrości ( $\varphi \imath \lambda$ „ ani nie dosiadają konia, jak wymagają tego sławni prawodawcy greccy i filozofowie, lecz podejmują się cięższej walki. Walka z diabłem i mocami [ciemności] wspólna jest zarówno dla nich, jak i dla mężczyzn, a słabość natury nigdzie nie stanowi dla kobiet przeszkody w tych bojach. Gdyż tego typu walki rozstrzygane są nie przez siłę ciała, lecz przez wolną decyzję duszy. Dlatego często kobiety walczyły mężniej niż mężczyźni i odnosiły świetniejsze triumfy"38.

Kto i jak zatem powinien wychowywać dziewczęta, by w przyszłości mogły stać się takimi dzielnymi niewiastami, by mogły jak najlepiej realizować to, do czego powołała je natura, by stawały się coraz bardziej podobne do swojego Stwórcy? Postawione tutaj pytania wyznaczają niejako kierunek pedagogicznej refleksji Chryzostoma. Postaramy się ją przybliżyć przedstawiając kolejno: środowisko wychowawcze i wychowawców, cele wychowania oraz metody wychowawcze.

2. Środowisko wychowawcze i wychowawcy. Mówiąc o uczeniu się kobiet w cichości Jan Chryzostom okazuje się rzecznikiem zastanych form wychowania. W starożytności bowiem wychowanie i edukacja dziewczą ${ }^{39}$ odbywała się na ogół w domu. Miała zatem charakter prywatny i rodzinny ${ }^{40}$. Córki rzadko kształcono poza domen - np. w szkołach ${ }^{41}$. Nawet w okresie wczesnego

\footnotetext{
${ }^{37}$ Por. Xenophon, De republica Lacedaemoniorum 1, 4; Plutarchus, Lycurgus 1, 4 (sam Plutarch bardzo życzliwie odnosi się do gimnastyki kobiet spartańskich).

${ }^{38}$ In Matthaeum hom. 8,4, PG 57, 87, ŹMT 18, 107-108.

${ }^{39}$ Ogólny pogląd na temat wychowania dziewcząt w starożytności przynosi praca H.I. Marrou, Historia wychowania w starożytności, tłum. S. Łoś, Warszawa 1969; zob. też L. Winniczuk, Ludzie, zwyczaje i obyczaje starożytnej w Grecji i Rzymie, Warszawa 1983, 271-305.

${ }^{40}$ Jedynie w Sparcie wychowanie dziewcząt było kwestią państwową i publiczną. Platon, nawiązując do tej tradycji, opowiedział się za podobnym wychowaniem (por. wyżej nota 9). Z kolei w Rzymie usiłowano kontrolować życie rodzinne poprzez instytucję cenzorów (potwierdzoną już w 2. poł. IV wieku przed Chr. - Cicero, De Republica 4, 6), która badała, czy ojcowie wywiązują się z obowiązków wobec synów; w mniejszym stopniu zajmowano się sprawą córek; zob. F. Wycisk, Rodzicielski obowiązek wychowania potomstwa w prawie rzymskim okresu republikańskiego, RTK 12 (1965) z. 5, 133; Eckmann, Starożytna rodzina grecka, s. 44.

${ }^{41}$ Jedną z najstarszych szkół dla dziewcząt był założony i kierowany przez Safonę (VII w.), tzw. „przybytek uczennic Muz”, istniejący na Lesbos; zwracano tam uwagę na muzykę, poezję i ćwiczenia fizyczne (Marrou, Historia wychowania, s. 70-72). W okresie hellenistycznym (od. III w. prz. Chr.) poświadczone jest istnienie szkół dla dziewcząt w Pergamonie, Smyrnie, na wyspie Teos (prawdopodobnie koedukacyjnej) oraz w Aleksandrii, gdzie dziewczęta mogły się kształcić na poziomie podstawowym i średnim (Marrou, Historia wychowania, s. 159 i 170). W Rzymie już w czasach republiki pojawiły się szkoły (tzw. poziom litteratora), do których chodziły uboższe dziewczęta (Marrou, Historia wychowania, s. 375, Winniczuk, Ludzie, zwyczaje, s. 252). Ponadto można wskazać przykłady kobiet, które zdobyły wyższe wykształcenie w różnych dziedzinach na-
} 
cesarstwa, kiedy to na Zachodzie upowszechniły się szkoły litteratora, pisarze rzymscy przedkładali edukację domową nad szkolną ${ }^{42}$. Mniej więcej w tym samym okresie w literaturze pedagogicznej i filozoficznej zaczęto zwracać uwag na wychowawczą rolę rodziny ${ }^{43}$, do której należeli: rodzice i rodzina męża, ponadto niewolnicy i wyzwoleńcy ${ }^{44}$. W przypadku dziewcząt dużą rolę (po rodzicach) odgrywali: niańka ( $\tau \rho \circ \varphi o ́ \varsigma, ~ \tau \imath \theta \eta ́ v \eta)^{45}$ i pedagog ( $\left.\pi \alpha \imath \delta \alpha \gamma \omega \gamma o ́ \varsigma\right)$, który mógł również zapewnić podopiecznej gruntowne wykształcenie ogólne ${ }^{46}$. O tym, iż pedagodzy dobrze spełniali swoją rolę w wychowywaniu dziewcząt świadczyć może stosunkowo duża liczba wykształconych kobiet w Cesarstwie Rzymskim $^{47}$.

uki: w filozofii - Hiparchii, uczennicy, później żony cynika Kratesa (Diogenes Laertius, De vita philosophorum VI 7, 96-98; Szymańska, Traktat Plutarcha z Cheronei, s. 28), Marcelliny, uczennicy gnostyka Karpokratesa, która w 1. połowie II w. założyła w Rzymie własną szkołę (Ireaneus, Adversus haereses, I 26,6; A. Zmorzanka, Marcellina, EK 11, 1226), Hypatii, najsławniejszej neoplatonki (M. Dzielska, Hypatia z Aleksandrii, Kraków 2006) oraz trzech innych neoplatonek - córki Olimpiodora oraz Edezji i Teodory (M. Dzielska, Aleksandryjki-uczone i nieznane, w: Byzantina Europaea. Księga Jubileuszowa ofiarowana Profesorowi Waldemarowi Ceranowi, red. M. Kokoszko - M.J. Leszka, Łódź 2007, 97nn; w dziedzinie matematyki - Pandrosjon (Dzielska, Aleksandryjki, s. 98-99); w alchemii - Marii Żydówki (R. Bugaj, Hermetyzm, t. 1, Warszawa 1998, 131-136).

${ }^{42}$ Taką formę kształcenia pochwalał m.in. Pliniusz Młodszy, ceniąc ją bardziej od edukacji w szkole publicznej (Plinius Minor, Epistulae V 16, 3; zob. Marrou, Historia wychowania, s. 375).

${ }^{43}$ Jej znaczenie podkreślali m.in. tacy pisarze jak Seneka (De consolatione ad Helviam, De beneficiis) i Plutarch (uwagi na ten temat w: De amore prolis); spośród pisarzy chrześcijańskich należało by wymienić: Tertuliana, Laktancjusza i Ambrożego (por. Kosznicki, Kształcenie i wychowanie, s. 82-87).

${ }^{44}$ Por. Kosznicki, Kształcenie $i$ wychowanie, s. 135.

${ }^{45}$ Niańki odgrywały dużą rolę zwłaszcza w początkowym okresie życia dziecka (pielęgnacja, opieka, zabawa); wraz z latami malała jej rola. W przypadku dziewczynek piastunka stawała się niekiedy w późniejszym okresie powiernicą wychowanki (np. piastunka Fedry, Klitajmestry - zob. Seneca, Phedra; tenże, Agamemnon). Na ogół chwalono ich oddanie (np. Swetoniusz w Żywotach cezarów). Instytucja nianiek miała też swoich przeciwników. Piastunki krytykowali: Tacyt za niski poziom i opowiadanie nieprawdziwych historii (Dialogus de oratoribus, 29-30), Ambroży za to, że osłabiają naturalną więź z matką (Hexsameron V 18), Plutarch za nadmierną pedanterię (De vitioso pudore 2) i nadopiekuńczość (Quaestiones convivales 5). Starożytni pedagodzy starali się uwrażliwić rodziców, by zwracali uwagę na poprawność ich obyczajów i mowy (Quintilianus, Institutio oratoria I 1, 4); Hieronim zwraca zaś konkretnie uwagę na to, by nie była pijaczką i nie plotkowała (Epistula ad Laetam 4); por. K. Korus, Program wychowawczy Plutarcha z Cheronei, Wrocław 1978, 41; Stępniewska, Wychowanie rodzinne dziewczat, s. 153; Kosznicki, Ksztatcenie $i$ wychowanie, s. 135; I. Błaszczyk, Seneka o wychowaniu w rodzinie rzymskiej, Bydgoszcz 2003, 174-175.

${ }^{46}$ Pedagodzy, najczęściej niewolnicy lub wyzwoleńcy (opiekujący się dzieckiem w drodze do szkoły), często z racji swojego wykształcenia stawali się prawdziwymi wychowawcami (nauczycielami) dziecka. H.I. Marrou (Historia wychowania, s. 376) zwraca uwagę na ich pozytywną rolę w edukacji kobiet.

${ }^{47}$ Ważnym źródłem są tu listy, np. list Ptolomeusza Do Flory, listy Hieronima do Marceli, Jana Chryzostoma do Olimpii; ich treść świadczy o znakomitym wykształceniu ich adresatek, por. np. E.E. Best, Cicero, Livy and educated Roman Women, „Classical Journal” 65 (1970) 199-204; 
Jan Chryzostom, uwzględniając tradycję i realia ówczesnej familii, jako opiekunów, wychowawców oraz nauczycieli dziewcząt, również wskazuje na poszczególnych członków rodziny ${ }^{48}$ : rodziców, niańkę i sługi, jako wypełniających tę funkcję ${ }^{49}$. Stosunkowo mało miejsca poświęca jednak takim postaciom, jak piastunka i służba. Na odnotowanie zasługuje również fakt, iż w swoich wypowiedziach pomija pedagoga ${ }^{50}$. Swoją uwagę koncentruje przede wszystkim na rodzicach.

Rodzice, według Złotoustego, godność wychowawców uzyskali przez zrodzenie swojego potomstwa ${ }^{51}$. W jednym z kazań na Księgę Rodzaju pisze bowiem, idąc za wczesniejszą tradycją ${ }^{52}$, że tak jak władza mężczyzny nad kobietą wynika ze stanu niewoli, tak władza rodziców nad dziećmi wynika $\mathrm{z}$,prawa natury":

„O innej jeszcze formie władzy chcę wam powiedzieć, która wywodzi podporządkowanie nie z grzechu, ale z natury. Jaka ona jest? Otóż jest to władza rodziców nad potomstwem. Ten przywilej jest odpłatą za bóle porodowe" ${ }^{n 3}$.

Błaszczyk, Seneka o wychowaniu, s. 108-117; R.M. Grant, A woman of Rome. The Matron i Justin, 2 Apology 2. 1-9, ChH 54 (1985) 461-472; Ph. Rousseau, ,,Learned women” and the development of a Christian culture in late antiquity, „Symbolae Osloenses” 70 (1995) 116-117; E.G. Hinson, Women biblical scholars in the late fourth century: the Arentine Circle, StPatr 33 (1997) 319324; W. Mayer, Constantinopolitan women in Chrysostom's circle, VigCh 53 (1999) 265-288; A. Stepniewska, Żeński klub inteligencji chrześcijańskiej na rzymskim Awentynie IV wieku, VoxP 22 (2002) t. 42-43, 261-292.

${ }^{48} \mathrm{Na}$ temat rodziny jako środowiska wychowawczego w nauczaniu Jana Chryzostoma por. Wójtowicz, Zadania rodziny chrześcijańskiej, s. 201-214; J. Krykowski, Nauka św. Jana Chryzostoma o matżeństwie, wychowaniu dzieci i ascezie, BOK 19, 31-32; A. Uciecha, Rodzina miejscem wychowania $w$ traktacie pedagogicznym o wychowaniu dzieci św. Jana Chryzostoma, ŚSHT 19-20 (1986-1987) 65-92; Kołosowski, Wychowanie religijno-moralne dzieci, s. 407.

${ }^{49}$ M. Falanga (Il pensiero pedagogico, s. 155 i 180, nota 396) powołując się na Dialog o kaptaństwie, wymienia jeszcze dziadków, ale sam Jan Chryzostom nie wspomina o nich w miejscu, do którego odwołuje się autor.

${ }^{50}$ Trudno stwierdzić, czy było to świadome pominięcie. Jeśli tak, to być może zadecydowały tu kwestie obyczajowe. Znane były bowiem przypadki oskarżeń wychowawcy i uczennicy o niemoralne zachowanie: np. córki Pontiusa Aufudianusa i jej nauczyciela (Valerius Maximus, Factorum et dictorum memorabilium VI 1, 2), czy Cecyliusza Epiroty i jego uczennicy (Marrou, Historia wychowania, s. 375; Wycisk, Rodzicielski obowiqzek wychowania, s. 140). Rolę pedagoga doceniali natomiast inni pisarze chrześcijańscy, np. Hieronim (Epistula ad Laetam 4). W traktacie $O$ wychowaniu dzieci Jan Chryzostom kilkakrotnie wspomina o zadaniach pedagoga, ale uwagi te odnoszą się do wychowania chłopców, por. De educandis liberis 37 i 59 .

${ }^{51}$ Warto przypomnieć, iż wychowanie dzieci było nie tylko przywilejem, ale również obowiązkiem, co w prawie rzymskim regulowała już tzw. ustawa Romulusa, por. Wycisk, Rodzicielski obowiazek wychowania, s. 132-133.

${ }^{52}$ Por. Seneca, De clementia I 13, 3; I 15, 1-2 i 7; I 22, 3; I 23, 1-3; Plutarchus, De amore prolis 3; K. Korus, Poglady Plutarcha na rolę ojca $w$ rodzinie, w: Rodzina w starożytnym Rzymie, red. J. Jundziłł, Bydgoszcz 1992, 53; Błaszczyk, Seneka o wychowaniu, s. 136.

${ }^{53}$ In Genesim sermo 4, 3, SCh 433, 242, ŹMT 45, 79. 
Zastanawia fakt, że nasz Antiocheńczyk nie podnosi wprost kwestii ich zewnętrznego wizerunku ${ }^{54}$, ani ich wykształcenia - w przeciwieństwie do pisarzy rzymskich ${ }^{55}$. Jednakże na podstawie traktatu $O$ wychowaniu dzieci można wnosić, że zakłada u nich pewną wiedzę, zwłaszcza religijną (znajomość Biblii, żywotów świętych) ${ }^{56}$. Ważnym czynnikiem w procesie wychowawczym jest, według niego, współdziałanie ojca i matki w wychowywaniu dzieci:

„Wy - ojcze i matko - musicie włożyć wiele starań w wychowanie swoich dzieci [...]. Tak i wy rodzice, [...] musicie wkładać wszystek trud, aby swe dzieci wychować na piękne obrazy Boga. Usuwajcie to, co nie potrzebne, uzupełniajcie braki" ${ }^{57}$.

W traktacie $O$ wychowaniu dzieci opowiada się jednak za podziałem zadań wychowawczych, przyjmując zasadę, że mężczyźni powinni mieć większy udział w edukacji chłopców, a kobiety - dziewczynek ${ }^{58}$, co nie znaczy, że matki nie uczestniczyły w wychowaniu synów ${ }^{59}$, a ojcowie córek. $\mathrm{Ci}$ ostatni $\mathrm{z}$ racji urzędu pater familias sprawowali nad córkami nadzór prawny ( $p a-$ tria potestas), jednakże relacje istniejące pomiędzy ojcem i córką miały też bardziej rodzinny charakter ${ }^{60}$. Sam Jan Chryzostom funkcji pater familias, oraz wynikającym z niej obowiązkom, starał się nadać dodatkowo sens teo-

${ }^{54}$ Chociaż zwraca np. uwagę na wygląd i postawę nauczyciela w szkole (In Matthaeum hom. 72, 2 i 74, 3); por. Ceran, Przykłady z życia wzięte, s. 158.

${ }^{55}$ Kwestię tę podejmował m.in. Kwintylian, który uważał, iż ojciec i matka powinni posiadać jak najwyższe wykształcenie i troszczyć się, by zapewnić je swoim dzieciom (Institutio oratoria I 1,6).

${ }^{56}$ Por. De educandis liberis 39, SCh 188, 130-136, BOK 19, 86-88.

${ }^{57}$ Tamże 22, SCh 188, 106-108, BOK 17, 81.

${ }^{58}$ Świadczyć o tym mogą np. uwagi, jakie spotykamy w traktacie $O$ wychowaniu dzieci, kierowane do ojców na temat wychowania synów i analogiczne - do matek na temat córek.

${ }^{59} \mathrm{~W}$ Rzymie i w Grecji matki zajmowały się synami do siódmego roku życia. W okresie Republiki, a później Cesarstwa, istniało nawet prawo pozwalające na przejęcie prawnej opieki nad synami w przypadku śmierci ojca (lub innych opiekunów w linii męskiej); przykładem mogą być matki sprawujące opiekę nad synami po śmierci męża: Kornelia (Quintitlianus, Institutionis oratoriae I 1, 4) oraz matka samego Jana Chryzostoma - Antuza. I. Błaszczyk wymienia (Seneka o wychowaniu, s. 112-113) również inne matki, które wywarły duży wpływ na życie synów - Marcję, Agrypinę Młodszą, Helvię. Wydaje się, że w rodzinach znanych naszemu Antiocheńczykowi, matki miały także duży wpływ na synów, skoro w swym traktacie $O$ wychowaniu dzieci poucza je, by powstrzymywały synów od picia alkoholu (tamże 90); jako zaś wzór właściwego stosunku matki do syna wskazuje na relację Anny i Samuela (In Ephesios hom. 21, 2; Szczur, Problematyka społeczna, s. 331); por. też K. Lutosławski, Wychowanie Ojców Kapadockich, AK 3 (1911) t. 5, 219-230, 326333 (św. Emmelia; św. Nonna); A. Stępniewska, Sylwia - matka papieża Grzegorza Wielkiego, VoxP 23 (2003) t. 44-45, 363-373; taż, Św. Emmelia - matka Bazylego Wielkiego i Grzegorza z Nyssy, VoxP 25 (2005) t. 48, 67-77; taż, Św. Nonna - matka Grzegorza z Nazjanzu, VoxP 28 (2008) t. 52/2, 1039-1048.

${ }^{60}$ Por. np. Epictetus, Diatribae I 11; szerzej na temat relacji ojca i córki por. J.P. Hallet, Fathers and daughters in Roman Society: women and the elite Family, Princeton 1984. 
logiczny. Woła bowiem: „Jesteś nauczycielem całej rodziny z nakazu Boga

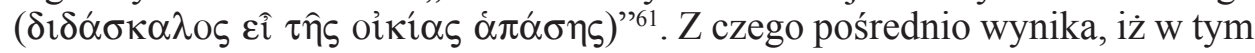
obszarze ojciec był nauczycielem córki w takim samym stopniu, w jakim był nim wobec innych członków rodziny. Jedyną z niewielu wypowiedzi, wskazujących wprost na relacje ojca i córki, znajdujemy w Dialogu o kapłaństwie, w którym nasz Kaznodzieja porównuje „ojca duchowego” do „ojca cielesnego", stwierdzając, iż ten ostatni ma o wiele lżejsze zadanie, niż kapłan, który troszczy się o wiernych:

„Ojciec cielesny ma wiele środków, by sobie ułatwić straż nad córką, bo i matka, i niańka, i sługi i bezpieczne mieszkanie pomagają mu w strzeżeniu dziewczyny"62.

Zadania, o jakich mówi tutaj nasz Antiocheńczyk, sprowadzają się faktycznie do surowego nadzoru nad córką: celem jest ochrona jej kondycji moralnej, obyczajów, dobrego imienia. Ojciec jest tutaj ukazany nie tyle jako wychowawca, ile jako strażnik dziewczyny. Postawa taka w okresie Cesarstwa cechowała - jak się wydaje - wielu ojców, zaś w literaturze można znaleźć liczne jej przykłady ${ }^{63}$. Jan Chryzostom potwierdza zatem jedynie słuszność takiego postępowania, czemu daje wyraz również w innym miejscu stwierdzając: „Gdy mamy córkę dziewicę, pilnie jej strzeżemy” ${ }^{4}$.

Drugą w kolejności wychowującą dziewczynę osobą, wymienioną w Dialogu o kapłaństwie, jest matka ${ }^{65}$, przedstawiana jako pomocnica ojca. W traktacie $O$ wychowaniu dzieci nasz Autor ukazuje ją jako główną wychowawczynię córki - zgodnie ze wspomnianą zasadą, by ojciec wychowywał chłopców, matka zaś dziewczynki; kieruje do niej następujące słowa:

„Niech i matka w podobny sposób trudzi się w wychowaniu córki. Przede wszystkim - niech ją oddala od przepychu świata i wszystkiego, za czym

${ }^{61}$ In illud: „Vidua eligatur” 9, PG 51, 321; Antiocheńczyk nawiązuje tutaj do idei Kościoła domowego, którego ojciec, jako pater familias, jest również jak biskup w kościele - nauczycielem, por. A. Bober, Rodzina Kościołem domowym wedtug św. Jana Chryzostoma, VoxP 5 (1985) z. 8-9, 193-199; S. Longosz, Rodzina wczesnochrzescijańska Kościołem domowym, RT 51 (2004) z. 10, 36-50 (Jan Chryzostom).

${ }^{62}$ De sacerdotio III 15, SCh 272, 214, tłum. W. Kania, POK 23, 75, przedruk BOK 1, 93.

${ }^{63}$ Swetoniusz w żywocie Boskiego Augusta (De vita caesarum. Divus Augustus 64, tłum. J. Niemirska-Pliszczyńska, Wrocław 1965, 152) pisze, że w taki właśnie sposób wychowywał swoją córkę, a później wnuczki August: „Córkę i wnuczki surowo wychowywał. Przyzwyczajał je do przędzenia, zabraniał mówić i czytać cośkolwiek po kryjomu oraz czego by nie można zapisać w jego domowym dzienniku. Niemniej surowo zabronił im widywać się z kimkolwiek poza domownikami”.

${ }^{64}$ In Matthaeum hom. 42, 4, PG 57, 450, ŹMT 23, 27.

${ }^{65}$ Por. wyżej nota 62 ; jej rola była szczególnie podkreślana przez starożytnych pisarzy pogańskich (zob. J. Jundziłł, Pochwała matek w literaturze czasów rzymskich-główne trendy rozwojowe, w: Rodzina w starożytnym Rzymie, Bydgoszcz 1993, 257-268; Błaszczyk, Seneka o wychowaniu, s. 138-157) i chrześcijańskich (zob. Kosznicki, Kształcenie i wychowanie, s. 88-111). 
gonią hetery. Niech i matka czyni wszystko, według wyżej podanych przepisów. Niech powstrzymuje matka syna i córkę od zbytku i pijaństwa - to jest najważniejszy środek do zachowania czystości" ${ }^{66}$.

Podobne wezwanie znajdujemy w 9. Homilii na I List do Tymoteusza:

„Matki, zajmujcie się przede wszystkim córkami! Łatwa to dla was straż. Czuwajcie" $"$.

Antiocheńczyk poprzez tego typu wezwania stara się im uświadomić, ciążący na nich obowiązek dobrego wychowania córki, wskazując też na pozytywne tego konsekwencje:

„Jeśli je tak ukształtujecie [ćwicząc w cnotach - A. Z.], ocalicie nie tylko córkę, ale i męża, który ją poślubi; nie tylko męża, lecz i synów; nie tylko synów, lecz i wnuków. Albowiem jeśli korzeń był dobry, to i pędy lepiej wybujają, a wy za to wszystko otrzymacie zapłatę"68.

Kobietę, która źle wychowuje córkę określa mianem dzieciobójcy

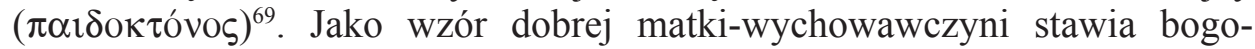
bojne i odważne matki przedstawione w Biblii, wskazując m.in. na matkę Machabeuszów:

„Niech słuchają matki, niech naśladują dzielność i miłość kobiety [matki Machabeuszy - A. Z.]. Niech tak wychowują dzieci"70.

Do listy osób odpowiedzialnych za wychowanie dziewcząt należałoby jeszcze dołączyć męża i kapłana. Do męża Złotousty zwraca się wielokrotnie jako do wychowawcy ,z urzędu”. Stanowisko to - jak wykazuje nasz Kaznodzieja - nabiera szczególnej wagi, gdy w domu rodzinnym żony zaniedbano jej wychowania (doprowadzając do rozwoju złych skłonności). W takim przypadku bowiem mąż powinien podjąć próbę naprawienia błędów matki i pomagać żonie pozbyć się niewłaściwych nawyków ${ }^{71}$. W jednej z Homilii na Ewangelię

${ }^{66}$ De educandis liberis 90, SCh 188, 196, BOK 19, 103.

${ }^{67}$ In Epistulam 1 ad Timotheum hom. 9, 2, PG 62, 346, tłum. T. Sinko: Św. Jan Złotousty, Homilie na Listy Pasterskie św. Pawła i na List do Filemona, Kraków 1949, 99.

${ }^{68}$ In Epistulam 1 ad Timotheum hom. 9, 2, PG 62, 346, T. Sinko, s. 100.

${ }^{69}$ In illud: ,, Vidua eligatur” 7, PG 51, 327: „Które w ten sposób nie wychowują, są raczej dzie-

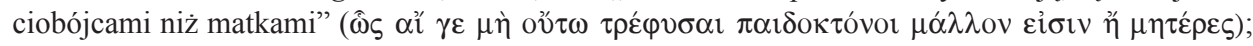
Seidlmayer, Die Pädagogik, s. 62.

${ }^{70}$ De Maccabeis 1, 3, PG 50, 621, PSP 8, 153; Falanga, Il pensiero pedagogico, s. 154; Szczur, Problematyka spoleczna, s. 327.

${ }^{71}$ Zgodne jest to z przedstawioną wcześniej Chryzostomową wizją męża jako pana i przewodnika żony. Idea męża-wychowawcy, która pojawiła się już u Sokratesa (Xenophon, Oeconomicus 5) i Plutarcha (Praecepta coniugalia) nie dziwi również z powodu wieku dziewcząt zawierających małżeństwo. Platon postulował dolną granicę na 16 rok życia (Leges VI 785 B), ustawy Augusta wskazywały na 20 rok; w praktyce za mąż wydawano już dziewczęta 12-14 letnie (zob. Plinius 
Mateusza radzi mu, by nie zniechęcał się do takiej małżonki, lecz pomagał jej stać się lepszą: ,niech jej mąż stara się usilnie na wszelki sposób ją poprawić"72. Z kolei zaś kapłana-wychowawcę reprezentuje sam Jan Chryzostom, który jako duszpasterz wielokrotnie zwracał się do młodzieży z pouczeniami. Przykład takiego pouczenia skierowanego bezpośrednio do dziewcząt znajdujemy w 49. Homilii na Ewangelię Mateusza:

„Powiedzieliśmy to nie tylko do młodzieńców, ale także do kobiet i dziewcząt. Bo i one podlegają takim błędom [chodzi tutaj o grzech próżności - A. Z.], $\mathrm{i}$ to o tyle bardziej, o ile bardziej pannie potrzebna jest skromność. Uważajcie zatem, że to, co zostało powiedziane do innych, zostało wystosowane również do was, abyśmy nie musieli ponownie tych samych rzeczy omawiać"’3.

Czego konkretnie uczył Antiocheńczyk opiekunów, wychowawców i nauczycieli dziewcząt? Czego uczył same dziewczęta? Czego od nich wymagał? Jaki ukazywał im cel? - na te pytania postaramy się odpowiedzieć poniżej.

3. Cele wychowania. Jan Chryzostom - jak zauważa Josephine Seidlmayer - nie miał (poza nielicznymi wyjątkami) dobrego mniemania o kobietach swojej epoki ${ }^{74}$. Uważał je za głupie i złośliwe oraz wskazywał na ich złe nawyki (pijaństwo, plotkarstwo, upadek obyczajów) ${ }^{75}$. Był jednak przekonany, że nie musiałyby być takie, gdyby w dzieciństwie otrzymały właściwe wychowanie. Za kondycję duchowo-moralną swoich dzieci w dużym stopniu czyni odpowiedzialnych wychowawców - rodziców. Oni bowiem, wychowując dziecko, są niczym malarze albo rzeźbiarze, którzy poprzez systematyczną pracę nad obrazem czy rzeźbą, kształtują je:

„Jak malarze nad obrazem i rzeźbiarze nad posągiem pracują z wielkim wysiłkiem tak wy - ojcze i matko - musicie włożyć wiele starań w wychowanie swych dzieci, tych podziwu godnych obrazów"76.

\footnotetext{
Minor, Epistulae V 16; por. Winniczuk, Ludzie, zwyczaje, s. 176 i 198). Obraz takiej właśnie młodocianej i niewykształconej żony ukazuje Ischomach w rozmowie z Sokratesem: „A cóż mogła umieć Sokratesie, skoro przyszła do mnie nie mając nawet jeszcze lat piętnastu, a przedtem całe życie dbano usilnie, aby jak najmniej widziała, jak najmniej słyszała, jak najmniej zadawała pytań?" (Xenophon, Oeconomicus 5, thum. S. Srebrny, w: Ksenofont, Wybór pism, oprac. J. Schnayder, BN II 39, Wrocław 1966, 128.

${ }^{72}$ In Mathaeum hom. 30,5, PG 57, 368, ŹMT 18, 361; por. In Epistulam ad Ephesios hom. 20, 8, PG 62, 147.

${ }^{73}$ Tamże 49, 6, PG 58, 504, ŹMT 23, 101.

${ }^{74}$ Por. Seidlmayer, Die Pädagogik, s. 59.

${ }^{75}$ Por. Quales ducendae sint uxores 2, PG 51, 227; In Titum hom. 4, 1; zob. Seidlmeyer, Die Pädagogik, jw., Szczur, Problematyka społeczna, s. 440.

${ }^{76}$ De educandis liberis 22, SCh 188, 106, BOK 19, 81; zob. też In Ephesios hom. 21, 1, 4; Plato, Leges 738E; Respublica II 377A-B; Aristoteles, Politica 1336a, 10; Quintilianus, Institutio oratoria II 19, 3; Pseudo-Plutarchus, De liberis educandis. Moralia 3E-F.
} 
Celem tych zabiegów, według Jana Chryzostoma, było, jeśli chodzi o chłopca - uformowanie atlety-żołnierza dla Chrystusa ${ }^{77}$, jeśli zaś o dziewczynę - ukształtowanie w niej takich cnót i przymiotów, któreby w przyszłości uczyniły z niej dobrą chrześcijańską żonę i matkę ${ }^{78}$. Złotousty uznawał tedy rozwijanie cnót ${ }^{79} \mathrm{~W}$ dziecku za cel nadrzędny. Wielokrotnie podkreślał bowiem potrzebę „naśladowania w cnotach”, „ubiegania się” o nie, czy dochodzenia do nich, stwierdzając tym samym, iż nie są one dyspozycjami wrodzonymi, lecz rozwijane są $\mathrm{w}$ trakcie długotrwałego procesu ${ }^{80}$ :

„Winniśmy się starać, by w domach naszego państwa rodziły się tylko cnoty, $\mathrm{i}$ by te cnoty rodziły znowu bogatych w cnoty, a nie występnych obywateli.

Bo duchowe zdolności człowieka są zarazem płodnymi matkami, rodzącymi dobre lub złe usposobienie" $" 1$

Rozwijając je człowiek, upodobnia się coraz bardziej do Boga ${ }^{82}$, kształtuje dobre usposobienie, staje się szczęśliwy ${ }^{83}$. Nasz Antiocheńczyk nie wyróżnia cnót typowo kobiecych, czy typowo męskich ${ }^{84}$. Uważa jedynie, że kobiecie

${ }^{77}$ Por. De educandis liberis 19, SCh 188, 102, BOK 19, 81: „Wychowaj żołnierza dla Chrystusa”

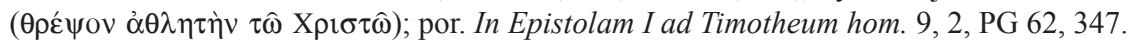

${ }^{78}$ Już w przedchrześcijańskim Rzymie ideałem była kobieta posiadająca wiele zalet. T. Mikocki (Zgodna, pobozna, skromna, piękna: propaganda cnót żeńskich w sztuce rzymskiej, Wrocław 1997) zwraca uwagę na takie przymioty, jak: concordia, pietas, fecunditas i pudicitia.

${ }^{79}$ Antiocheńczyk cnotę pojmował klasycznie, jako pozytywną cechę moralną, stałą dyspozycję do dobra (zob. definicję: Z. Pańpuch, Cnoty $i$ wady, PEF II, Lublin 2001, 216-231).

${ }^{80}$ Problem taki postawił m.in. Plutarch w diatrybie Czy cnoty można się nauczyć: „Czyż nie jeszcze śmieszniejszy będzie ten, kto dowodzi, że jedynie roztropności [Plutarch spośród cnót stawia ją na najwyższym miejszu - A. Z.] nie można zdobyć przez naukę; a wszak bez niej ze wszystkich innych sztuk nie ma żadnego pożytku ani zysku" (An virtus doceri possit 3 , thum. Z. Abramowiczówna: Plutarch, Moralia, I, Biblioteka Klasyków Filozofii 123, Warszawa 1977, 8); zob. też Plutarchowe diatryby: De virtute morali i De profectibus in virtute; por. In Matthaeum hom. 34, 5, PG 57, 394, ŹMT 18, 409: „dusza, choćby była brzydka, prędko może stać się piękna”

${ }^{81}$ De educandis liberis 65 , SCh 188, 164, BOK 19, 95. Na uwagę zasługuje określenie „w domach naszego państwa”, które oznacza tutaj poszczególne części ciała: piersi (serce), lędźwie i mózg, w których „mieszkają" poszczególne cnoty.

${ }^{82}$ Por. In Genesim sermo 3, 1, SCh 433, 204, ŹMT 45, 69. Podobny pogląd głosił Muzoniusz,

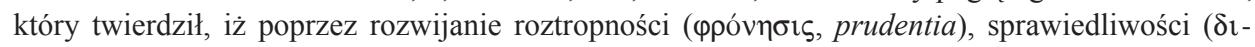


wiek rozwija w sobie boskie cechy; zob. J.T. Dillon, Musonius Rufus and education in the Good Life: a model of teaching and living virtue, Dallas 2004.

${ }^{83}$ Por. In Epistolam ad Romanos hom. 1, 4, PG 60, 400, thum. T. Sinko: Św. Jan Chryzostom, Homilie na list św. Pawła do Rzymian, oprac. A. Baron, Kraków 1995, 48: „Jeśli chcemy zażywać rozkoszy, uciekajmy przede wszystkim przed nieprawością, a ubiegajmy się o cnoty"; por. tamże 1, 4, PG 60, 400, T. Sinko, s. 47: „Albowiem pogodę ducha i radość daje zwykle nie wielkość urzędu, nie mnogość pieniędzy, nie pycha potęgi, nie siła ciała, nie kosztowność stołu, nie strojność szat ani żadna inna rzecz ludzka, lecz jedynie dobry stan duchowy i dobre sumienie".

${ }^{84}$ Podobny pogląd głosił Plutarch; w Mulierum virtutes wymienił następujące cnoty, które w takim samym stopniu przysługują mężczyznom, jak i kobietom, a są to (według J. Boulogne - po- 
jako słabszej i przeznaczonej do życia „w poddaństwie” w dochodzeniu do nich powinni pomagać: ojciec, matka i mąż ${ }^{85}$ W jednej z Homilii na List do Efezjan mówi:

„Niech [mąż - A. Z.] doprowadzi ją do najpiękniejszego stanu - do cnoty”"

Istotne jest to, że pomimo uznania słabszej pozycji kobiety, nie umniejsza (o czym już wspomniano) jej wytrwałości w zdobywaniu cnót. Co więcej, uważa, że niektóre niewiasty w cnotach mogą nawet przewyższyć mężczyzn ${ }^{87}$.

Jakie tedy cnoty powinny rozwijać w sobie dziewczęta? Na to pytanie trudno jest odpowiedzieć jednoznacznie, bowiem Złotousty nigdzie szerzej nie omówił tej kwestii, tak jak nie nie przedstawił swojej aretologii w sposób systematyczny. Na uwagę zasługuje niewątpliwie klasyfikacja, jaką przedstawia w traktacie $O$ wychowaniu dzieci, gdzie wyróżnia trzy cnoty (pokój i uległość, czystość, mądrość) i trzy odpowiadające im wady (porywczość i upór, bezwstyd, głupota), które stanowią pozytywny lub negatywny stan trzech dyspozycji „matek” (określanych jako domy, siedziby): męstwa, miłości ${ }^{88}$ i rozumu:

„Cnotami męstwa są pokój i uległość, a jego wadami porywczość i upór. Cnotami miłości jest czystość, jego wadą - bezwstyd. Cnotą rozumu jest mądrość jego wadą - głupota" ${ }^{99}$.

Do tych trzech (a może sześciu?) cnót należy jeszcze dodać skromność ( $\mu \varepsilon \tau \rho ı$ ¿nๆs), której Antiocheńczyk poświęca stosunkowo dużo miejsca w swoich homiliach. Jej znaczenie (dla rozwoju duchowego) ukazuje w kontekście negatywnego odpowiednika, jakim jest próżność (űßıı). O tej zaś wadzie pisze tak:

„Próżność jest podobna do owocu Sodomy. Z zewnątrz jest on piękny i temu, kto na niego spojrzy, wydaje się zdrowy (...) Podobnie jest z próżnością. Z zewnętrznego wyglądu jest piękna i czarująca, spróbujmy ją jednak zatrzymać, a zaraz ściągnie naszą duszę do pyłu" ${ }^{\prime 0}$.

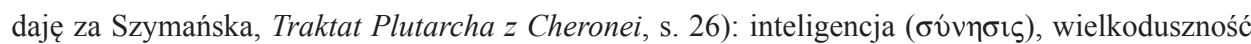

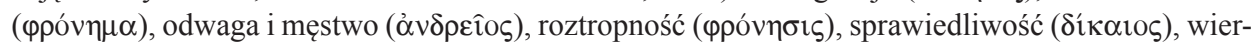

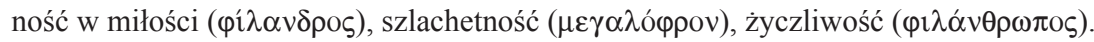

${ }^{85}$ Por. Falanga, Il pensiero pedagogico, s. 153.

${ }^{86}$ In Epistolam ad Ephesios hom. 20, 8, PG 62, 147, BOK 19, 65.

${ }^{87}$ Przykładami takich dzielnych kobiet są dla Chryzostoma np. Italika i Pentadia, por. Epistula 170 (ad Italicam), PG 52, 709-710, thum. W. Kania, PSP 13, 300-301; Epistula 185 (ad Pentadiam diaconissam), PG 52, 716, thum. W. Kania, PSP 13, 301: „znam bowiem twego wielkiego i wzniosłego ducha [...]. Okazałaś to czynem i sława tego doszła na krańce ziemi”. Uważa też, że mężczyzna chętnie słucha roztropnej kobiety, zob. In Joannem hom. 61, 4, PG 59, 340

${ }^{88} \mathrm{~W}$ innych miejscach pisze, iż jest to cnota podstawowa, por. Szczur, Problematyka spoteczna, s. 325.

${ }^{89}$ De educandis liberis 65, SCh 188,162-164, BOK 19, 95.

${ }^{90}$ Tamże 3, SCh 188, 74, BOK 19, 74. 
Uważał, że jej wyrazem jest upodobanie do drogich szat, biżuterii i złota, oraz kosmetyków („,bielideł”) i perfum („wonności”), które szczególnie krytykował, podkreślając, iż: „Nic tak nie odbiera duszy gorliwości i nie czyni jej ospałą, jak upodobanie do przyjemnych zapachów"91. Młodzież, która w takich rzeczach znajduje upodobanie, zasługuje, jego zdaniem, na najwyższe potępienie. Powołując się na słowa św. Pawła z I Listu do Tymoteusza ${ }^{92}$, mówi:

„Czyż zasłużysz na jakieś przebaczenie [mówi to do młodzieńców i dziewcząt - A. Z.] , jeśli Paweł nie pozwala mężatce nosić drogich szat, a ty nawet $\mathrm{z}$ obuwiem łączysz tę głupotę [...] i wymyślasz tysiące rzeczy dla tej ośmieszającej próżności" ${ }^{\prime 93}$.

Upodobanie do zbytku odwraca uwagę - jak wykazuje to dalej - od istotnych spraw: życzliwości, współczucia, miłości bliźniego i miłosierdzia ${ }^{94}$. Dusza takiego człowieka staje się ,nieludzka”, próżna i dziwaczna ${ }^{95}$. Człowiek taki może się też przyczynić do poważnych kłopotów materialnych rodziny:

„Kto przyzwyczaił się przepadać bez opamiętania za takimi rzeczami, ten potrzebuje wielkich wydatków, a także wielkich dochodów na stroje i na wszystkie inne rzeczy" ${ }^{\prime \prime}$.

Dlatego też Złotousty wzywa matki, by nie przyzwyczajały swoich córek w domu rodzinnym do zbytku: taka bowiem dziewczyna jako żona stanie się prawdziwym utrapieniem męża:

„Jeśli dziewczyna przyzwyczaiła się w pokoju matczynym do kobiecych ozdób, po opuszczeniu domu stale będzie przykra dla męża i spowoduje mu więcej kłopotu niż poborca podatków" $"$.

Mając na uwadze dobro przyszłej rodziny, zaleca ponadto matkom, aby przygotowywały córki, ucząc je m.in. „umiejętności życia”, która pomoże jej w przyszłości radzić sobie z czekającymi ją obowiązkami:

„Tak więc zawsze postępujmy [z córką - A. Z.], jakbyśmy dbali o pożytek nie jednej duszy, lecz przez jedną o pożytek wielu. Tak bowiem należy córce z ojcowskiego domu wychodzić do ślubu, jak atlecie ze szkoły ćwiczeń;

${ }^{91}$ Tamże 54, SCh 188, 152-154, BOK 19, 93.

${ }^{92}$ Por. Epistola I ad Timotheum 2, 9: „Podobnie kobiety - w skromnym zdobnym odzieniu, niech się przyozdabiają ze wstydliwością i umiarem, nie przesadnie zaplatanymi włosami albo złotem czy perłami, albo kosztownym strojem".

${ }_{93}^{93}$ In Matthaeum hom. 49, 5, PG 58, 502, ŹMT 23, 98.

${ }^{94}$ Por. jw.

${ }^{95}$ Por. In Matthaeum hom. 49, 5, PG 58, 502, ŹMT 23, 99: „Świadczy to, że dusza jest zniewieściała, nieludzka, próżna i dziwaczna. Kiedyż ktoś zajmujący się takimi niepotrzebnymi rzeczami zdoła zwrócić uwagę ku czemuś, co jest koniecznie potrzebne?"

${ }^{96}$ Tamże 49, 6, PG 58, 503, ŹMT 23, 100.

${ }^{97}$ De educandis liberis 17, SCh 188, 100, BOK 19, 80. 
powinna posiadać tak dokładną umiejętność życia, która by, jak zaczyn całe ciasto, miała doprowadzić do piękności"98

Umiejętności te nasz Antiocheńczyk wiąże nie tylko ze sferą duchową, ale też z zadaniami właściwymi płci niewieściej. Tutaj okazuje się zwolennikiem tradycyjnego podziału prac, przydając - jak zauważa J. Seidlmayer - mężczyźnie oszczep, a kobiecie wrzeciono ${ }^{99}$. Dziewczęta winny się zatem uczyć prac domowych, oraz zapoznwać się z zasadami zarządzania domem i dbania o służbę, bowiem takie będą w przyszłości ich zadania jako żon ${ }^{100}$ :

„Zadaniem kobiety jest jedno: zachowanie całości spraw domowych, czuwanie nad dochodami i troska o gospodarstwo domowe"101.

Jan Chryzostom, mimo iż zalecał tradycyjne wychowanie, nie pochwalał jednak nadmiernego izolowania dziewcząt od świata zewnętrznego, jakie często obserwował. Krytycznie wypowiadał się o rodzicach, którzy pozwalali dziewczętom jedynie na rozmowę z krewnymi ${ }^{102}$, czy zabraniali jej rozmowy

${ }^{98}$ In Epistolam I ad Timotheum hom. 9, 2, PG 62, 347, thum. T. Sinko, s. 100-101; H.I Marrou (Historia wychowania, s. 197), zwracając uwagę na „obfitość metafor związanych z atletyką”, jaką spotyka się w literaturze chrześcijańskiej do czasów Jana Chryzostoma, uważa, że wskazywałoby to na istniejącą jeszcze w owych czasach popularność zawodów sportowych.

${ }^{99}$ Por. Seidlmayer, Die Pädagogik, s. 61; Joannes Chrysostomus, Quales ducendae sint uxores 4, PG 51, 231: „Nie może kobieta potrząsać włócznią, nie może rzucać oszczepem, ale może prząść

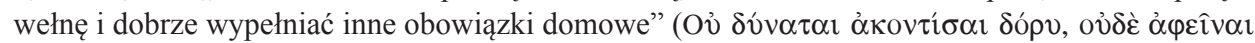

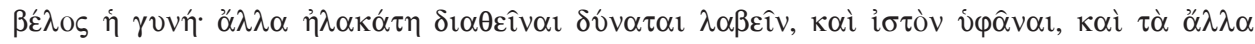


toposu przedstawiającego kobietę z wrzecionem lub przy warsztacie tkackim (np. Ilias XXII 405515; Odysseia VI 49-321). Te często spotykane w literaturze wątki odzwierciedlały faktyczną sytuację (zob. Xenophon, Oeconomicus 5; Diogenes Laertius, De vita philosophorum II 5; Lucianus, Dialogi meretricii). Przeciwko pracom domowym dziewcząt (m.in. przędzeniu wełny i tkaniu) miał się wypowiedzieć Likurg (Xenophon, De republica Lacedaemoniorum I 3-10) oraz Platon, który takie życie nazywał pustym; jako wzór stawiał dziewczętom ateńskim kobiety spartańskie (Leges 804E-806C; 813E-814C). Potwierdzenie tej opinii znajdujemy w epigramacie Erinny, która przedstawia dramatyczną sytuację młodziutkiej poetki, stojącej przy krosnach i „strzegącej” wrzeciona (Anthologia Palatina IX 190).

${ }^{100}$ Dobrze pokazuje to Ksenofont, por. Oeconomicus 5, tłum. Z. Abramowiczówna, s. 132: „,będziesz musiała w domu siedzieć, wysyłać na robotę tych ze służby, którzy pracować mają poza domem, a kierować tymi, którym praca w domu przypada, przyjmować wszystko, co do domu przynoszą, i z tego rozdzielać między ludzi tę część, która przeznaczona jest na spożycie, a co do reszty dbać i pilnować, by zapasy, przeznaczone na rok, nie rozeszły się w ciągu miesiąca”.

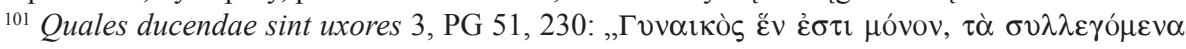

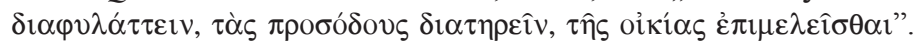

${ }^{102}$ Por. In illud: „,Propter fornicationes uxorem” 2, PG 51, 211: „Tyle czasu poświęcił ojciec wraz z matką strzegąc dziewczyny [...] temu miały służyć osobne pokoje, [...] a kiedy wychodziła wieczorem czyniono wszystko, by nikt nawet z najbliższych osób jej nie widział”. 
z narzeczonym do momentu ślubu ${ }^{103}$. Nasz Homileta uważał, że takie wychowanie czyni dziewczynę naiwną i bojaźliwą, przez co zaniedbuje ona później niekiedy uczynki miłosierdzia ${ }^{104}$. Wzorem dobrze wychowanej dziewczyny jest dla niego Rebeka, która nie siedziała, jak współczesne Janowi dziewczęta, w swojej komnacie, znała swojego przyszłego męża Jakuba, codziennie chodziła po wodę, a przy tym zachowywała się obyczajnie ${ }^{105}$.

4. Metody wychowawcze. Antiocheńczyk pokazuje, że ważna jest nie tylko świadomość celu wychowania (czyli tego, jakie cechy i umiejętności należy poprzez wychowanie kształtować w dziecku), lecz także wiedza: jak to należy robić. Dlatego też w traktacie $O$ wychowaniu dzieci sporo miejsca poświęcił metodom i środkom wychowawczym (choć może raczej należało by powiedzieć - zabiegom). Większość z nich dotyczy w takim samym stopniu chłopców, jak i dziewczynek, a są to: obserwacja, ,zamykanie bram, czyli kontrola zmysłów", uczenie poprzez przykład i lekturę, pouczenia i napomnienia.

Na rolę obserwacji w procesie wychowawczym zwracano uwagę już przed Janem Chryzostomem. Pisarzem, który szczególnie doceniał jej wartość, był Plutarch, który uważał, iż ,rodzice mają możność zaobserwować naturę swojego dziecka i swoje spostrzeżenia wykorzystać w pracy wychowawczej"106. Podobną myśl formułuje nasz Duszpasterz, który stwierdza, że rodzice obserwując syna czy córkę, mogą zauważyć ich skłonności, a znając je, mogą rozwijać te dobre, a wykorzeniać złe:

„Usuwajcie to, co niepotrzebne, uzupełniajcie braki, z dnia na dzień baczcie na skłonności swoich dzieci, na dobre by je rozwijać, na złe, by je wykorzeniać"107.

Z kolei metoda, którą nazwalibyśmy (idąc za intencją naszego Autora) ,zamykaniem bram”, odwołuje się do idei pięciu zmysłów, określanych tutaj

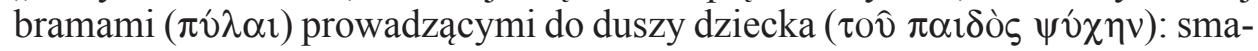
ku (języka), słuchu, wzroku, powonienia i dotyku ${ }^{108}$. Antiocheńczyk zdawał sobie sprawę, iż tą drogą do umysłu dziecka wchodzą różne wrażenia - dobre i złe. A zatem należałoby zamykać zmysły dziecka (owe symboliczne bramy) przed dopływem złych bodźców, które mogą kazić jedynie jego duszę.

\footnotetext{
${ }^{103}$ Por. Quales ducendae sint uxores 4, PG 51, 231; Seidlmayer, Die Pädagogik, s. 62.

${ }^{104}$ Por. Quod regulares feminae viris cohabitare non debeant 7, PG 47, 527, thum. R. Sawa, VoxP 16 (1996) t. 30-31, 449.

105 Por. Quales ducendae sint uxores 7, PG 51, 236.

${ }^{106}$ Korus, Program wychowawczy, s. 41. Sam Plutarch stanowił przykład ojca, który posługiwał się tą metodą; w Liście pocieszającym do żony przedstawił np. spostrzeżenia wynikające z obserwacji córki Timokseny (Consolatio ad uxorem 2; Korus, Program wychowawczy, jw).

${ }^{107}$ De educandis liberis 22, SCh 188, 108, BOK 19, 81.

108 Por. tamże 27, SCh 188, 114, BOK 19, 82-83: „Bramami miasta są oczy, język, słuch, węch i jeśli chcesz również dotyk".
} 
Innymi słowy, rodzice powinni mieć świadomość, co dziecko mówi ${ }^{109}$, czego słucha $^{110}$, co ogląda ${ }^{111}$, jakie wonie do niego docierają ${ }^{112}, \mathrm{z}$ czym się fizycznie styka poprzez dotyk ${ }^{113}$.

Ważną rolę w procesie wychowawczym pełni dobry przykład ${ }^{114}$, na co nasz Antiocheńczyk stara się uwrażliwić rodziców. Dla dziewczyny wzorem jest jej matka. Dlatego ważne jest, by stosownie się zachowywała i skromnie ubierała $^{115}$. Córka, patrząc na nią, nabiera podobnych upodobań:

„Masz córeczkę? Dbaj, by nie poniosła szkody naśladując twoje obyczaje, jak to zwykły czynić córki naśladując obyczaje matek. Bądź dla niej przykładem czystości, strój się w prawdziwe ozdoby, które upiększają duszę"116.

$\mathrm{Z}$ tego też powodu Złotousty gani złe nawyki matek ${ }^{117}$. Poza matką, dziewczyna może brać przykład z innych kobiet (np. postaci świętych) ${ }^{118}$. Jan zwraca ponadto uwagę na wzorce biblijne. Jego ulubioną postacią jaką daje za przykład matkom i córkom, jest Rebeka ${ }^{119}$, ale odwołuje się też do innych postaci

${ }^{109}$ Por. tamże 28, SCh 188, 116, BOK 19, 83: „Nauczmy dzieci wypowiadać tylko przystojne i pobożne słowa”; zob. In Epistulam ad Ephesios hom. 20, 7.

${ }^{110}$ De educandis liberis 38 , SCh 188, 128, BOK 19,86: „Nie powinny dzieci słyszeć złych mitów i bajek. (...) Niech za to słyszą inne historie, łatwe i proste opowiadania”. Podobny pogląd miał Kwintylian, który uważał, że nie powinno się opowiadać dziecku nieprawdziwych historii (por. nota 45).

${ }^{111}$ Antiocheńczyk radzi by odwrócić uwagę dziecka od piękna sztucznego, pokazując mu piękno natury (por. De educandis liberis 59, SCh 188, 156-158, BOK 19, 94). Zaleca, by zabronić chodzenia do teatru (dotyczy to przede wszystkim synów - tamże 56; dziewczęta, przebywające głównie w domu, mniej były narażone na te pokusy). Na temat widowisk i ich zgubnego wpływu na młodzież zob. S. Longosz, Widowiska teatralne zagrożeniem dla życia rodzinnego wedlug św. Jana Chryzostoma, w: Chrześcijanie a życie publiczne w Cesarstwie Rzymskim III-IV wieku, red. J. Śrutwa, Lublin 1988, 135-198.

${ }^{112}$ Por. De educandis liberis 54, SCh 152-154, BOK 19, 93. Antiocheńczyk zwraca tutaj uwagę, zwłaszcza dziewczętom, na szkodliwy wpływ wonności, które budzą „,zdrożne zachcianki” i „pokusy do grzechu".

${ }^{113}$ Por. tamże 63, SCh 188 162, BOK 19, 95: „Pozornie jest ona [brama - A. Z.] zamknięta, a jednak pozwala wszystkiemu dostać się do wnętrza, jakby była otwarta. Nie dopuśćmy do wydelikacenia ciała przez szaty ani do poufałego zetknięcia się z ciałem innego człowieka".

${ }^{114}$ Por. tamże 70; In Epistulam ad Epheseis hom. 20, 8. Podejmując kwestię przykładu (wzoru) Jan Chryzostom (podobnie jak wcześniej Plutarch) wpisuje się w tradycję greckiej pajdei, odwołującej się m.in. do analogii, jaka zachodzi pomiędzy procesem tworzenia a procesem wychowania (czego przykład znajdujemy w De educandis liberis 22); por. W. Jaeger, Paideia, thum. M. Plezia - H. Bednarek, Warszawa 2001, 37-38; Korus, Program wychowawczy, s. 41.

${ }^{115} \mathrm{Na}$ temat tego, jak powinna ubierać się żona i matka por. In Epistulam ad Epheseis hom. $20,7$.

${ }^{116}$ In Epistolam ad Colossenses hom. 10, 5, PG 62, 374.

${ }^{117}$ Por. nota 96.

${ }^{118}$ Chodzi tutaj o postać męczennicy Domniny, którą wspomina z powodu jej cnót w homilii De ss. Martyribus Berenice et Prosdoce 7, PG 50, 639-640; zob. Falanga, Il pensiero pedagogico, s. 154 i 180 (nota 385 ).

${ }^{119}$ Por. wyżej nota 104. 
- Sary, Debory i Racheli, a także Anny ${ }^{120}$. Dziewczynki (tak jak i chłopcy) mogą się o nich dowiadywać z opowiadań ojca, który powinien systematycznie przedstawiać dzieciom różne historie $\mathrm{z}$ dziejów biblijnych ${ }^{121}$.

Jan Chryzostom zwraca uwagę, że rodzice przede wszystkim powinni pouczać dziecko, zwłaszcza w sprawach religijnych, bo, jak powiada: „Jeśli dzieci od młodości wzrastać będą bez pouczenia, cóż z nich będzie?" ${ }^{22}$. Powinni mu przy tym pokazywać, co jest dobre, a co złe:

„Gdy dobre zasady zapadną w serce, nikt nie potrafi ich wyrwać. Umocnią się one jak zastygła pieczęć na miękkim wosku"123.

Przypomina jednak, że wymagania powinny być dostosowane do możliwości dziecka, nie mogą być ponad miarę ${ }^{124}$.

Odrębną grupę stanowią metody, jakie zaleca nasz Antiocheńczyk mężom, którzy pragną „wychować” swoją żonę. W jednej z Homilii na Ewangelię Mateusza, podaje wskazówki, jak mają postępować, by oduczyć ją używania kosmetyków i noszenia ozdób. Sposób, który zaleca, można umownie nazwać metodą „stopniowych zmian”. Polega ona na tym, by zaczynać od rzeczy drobnych i takich na których jej mniej zależy, należy przy tym chwalić piękno naturalne, a ganić sztuczne; mówić jej, że bez „bielidła” i „różu” wygląda o wiele ładniej; powoływać się przy tym na opinię innych osób ${ }^{125}$.

Jan Chryzostom wielokrotnie przypomina wychowawcom (rodzicom, mężom), że ich zabiegi powinna cechować postawa miłości, łagodności (dziewczynie, żonie nie należy okazywać niezadowolenia i nadmiernie jej krytykować), cierpliwości (nie należy jej ponaglać) ${ }^{126}$. Od tego w dużej mierze zależy powodzenie ich starań i trudów wychowawczych.

Pomimo, iż Jan Chryzostom nie przedstawił nigdzie w sposób systematyczny swoich poglądów na temat wychowania dziewcząt (wypowiedzi na ten temat są bowiem krótkie i rozproszone), można zaryzykować stwierdzenie, iż przedstawił konsekwentny ,program” edukacyjny, wskazując na cele wychowania i jego metody. Opierając się na założeniach antropologii biblijnej (stworzenie człowieka

${ }^{120}$ Zob. In Epistulam ad Ephesios hom. 13, 4 i De Anna sermones 1-5; Falanga, Il pensiero pedagogico, s. 154 (noty 382 i 384 ).

${ }^{121}$ Por. De educandis liberis 39-45.

${ }_{122}$ Tamże 18, SCh 188, 100, BOK 19, 80; zob. W. Kania, Pierwsza katecheza domowa w ujęciu św. Jana Chryzostoma, VoxP 5 (1985) z. 8-9, 215-222.

${ }^{123}$ De educandis liberis 20, SCh 188, 104, BOK 19, 81.

${ }^{124}$ Por. In Epistulam ad Ephesios hom. 20, 6.

${ }^{125}$ Por. In Matthaeum hom. 30, 5, PG 57, 182, ŹMT 18, 361; zob. też In Epistulam ad Ephesios hom. $20,7$.

${ }^{126}$ Por. De educandis liberis 72-73; In Epistulam ad Ephesios hom. 20, 6. 
na obraz Boga, wezwanie kobiety do poddania mężczyźnie oraz do małżeństwa i macierzyństwa), uważał, że dziewczęta powinno się wychowywać tak, by mogły dobrze realizować przeznaczenie właściwe swojej płci. Stąd podkreślał wage ich rozwoju duchowo-moralnego (w którym może pomóc dobre wychowanie) oraz potrzebę uczenia rzeczy praktycznych. Rady jakie dawał wychowawcom, wskazują na dobrą znajomość natury człowieka, ludzkich charakterów, ówczesnych stosunków rodzinnych. W wielu przypadkach zdumiewa ich uniwersalność (chociaż może nie należałoby się dziwić, wszak natura ludzka jest niezmienna) oraz trzeźwe podejście - tę cechę podkreśla zwłaszcza J. Seidlmayer ${ }^{127}$. Szkoda jedynie, iż pominął prawie całkowicie sprawę intelektualnego rozwoju dziewcząt, mimo iż zdawał sobie sprawę z możliwości ich umysłu ${ }^{128}$.

\section{DIE MÄDCHENERZIEHUNG IN DER LEHRE JOHANNES CHRISOSTOMUS}

\section{(Zusammenfassung)}

Die Verfasserin zeigt bei der Besprechung der Lehre des hl. Johannes Chrisostomus zum Thema der Mädchenerzierhung, dass sie ihre Grundlagen in der biblischen Anthropologie hatte. In Bezug auf drei ersten Abschnitte des Buches Genesis und auf Kommentare des hl. Paulus deutet er darauf, dass die Frau wie der Mann nach dem Bild und Ähnlichkeit des Schöpfers geschaffen ist und zweitens, dass die nach dem Fall aus dem Paradies die Freiheit verloren hat ( die mit dem Sein als das Bild verbunden ist) und dadurch wurde sie dem Mann untertan (Johannes Chrisostomus fügt noch das Lehrverbot und Befehl des Lernens zu Hause hinzu) und nahm neue Berufung zur Ehe und Mutterschaft an, verlor sie aber die Fähigkeit nicht, dem Gott durch Tugenden angleichen. Die Verfasserin bespricht dann drei Gruppen der Fragen, die nach der Analyse der Meinungen des Antiochieners zum Thema der Erziehung zu unterscheiden sind. Es sind die Erzieher - vor allem der Vater, die Mutter und der Ehemann, die Erzeihungsziele - solche wie geistig-moralische Entwicklung und praktische Fähigkeiten, verbunden mit dem weiblichen Geschlecht zuständigen Aufgaben und auch die Methoden (Beobachtung des Kindes, sog. „Torsperren”, also das Kontrollieren dessen, was das Kind mit Sinnen erkennt, die Belehrungen und Mahnungen und auch Verfahren der ,stufenweisen Begrenzung”, das beim Abgewöhnen von schlechten Gewohnheiten und Neigungen verwendet ist.

127 Chodzi tutaj zwłaszcza o pogląd, by nie izolować dziewcząt nadmiernie od świata, por. Seidlmayer, Die Pädagogik, s. 62: „Chrysostomus aber, gesunden Sinnes wie immer in pädagogischen Fragen, hält dies nicht einmal für den Idealzustand, sondern er wünscht, dass die goldene Mitte zwischen gänzlicher Abgeschiedenheit und häufigen Aufenthalt in der Oeffentlichkeit eingehalten werde".

${ }^{128}$ Kwestię tę zaczęli natomiast podejmować inni pisarze chrześcijańscy - Ambroży i Hieronim, por. Stępniewska, Wychowanie dziewcząt w pedagogice św. Hieronima, s. 151-176; V. Milazzo, Educare una vergine: precetti e modeli in Ambrogio e Gerolamo, Catania 2002, 59-70. 